$\overline{\text { 総 説 }}$

\title{
C型肝炎ウイルスの持続感染機序と 肝発癌機構についての一考察
}

\author{
日野啓輔 \\ 山口大学医学部保健学科基礎検査学講座 宇部市南小串 1 丁目 1 - 1 （下755-8505） \\ Key words：C型肝炎ウイルス，遺伝子変異，酸化ストレス，鉄過㮃，肝細胞癌
}

和 文 抄 録

著者は山口大学医学部第一内科入局以来, 主にウ イルス性肝炎の病態と治療に関する研究を行ってき た。本総説ではC型肝炎ウイルス $(\mathrm{HCV})$ の持続感 染機序と肝発癌機構についてわれわれのデー夕を紹 介しながら考察を行った。 HCVが末梢血単核球細 胞内に感染することにより宿主の免疫応答から回避 する可能性や，外被タンパク内に存在する超可変領 域の変異を繰り返すことによる中和抗体からの逃避 が持続感染機序の一要因と考えられた。こうした $\mathrm{HCV}$ 持続感染は究極的には高率な肝細胞癌の発生 へと慗がるが，肝発癌にはHCVがもたらす酸化ス トレスが関与していると考えられる。しかし， HCVのみの酸化ストレスでは肝発癌には不十分で あり，酸化ストレスを増強する2nd hitが重要と考 えられる。臨床的には加龄，アルコールなど酸化ス トレス増強因子はいくつか上げられるが，われわれ はC 型肝炎病態の特徵の一つである肝内鉄過剩に注 目しC型慢性肝炎の鉄過剩状態に類似したHCVトラ ンスジェニックマウスを作成し, 肝発癌機構の解析 を行った，その結果， HCV感染に扔ける鉄過剩状 態はミトコンドリア障害を引き起こし, 酸化ストレ スを増強することで肝発癌を促進することが明らか となった。今後はこの発癌モデルを利用して，C型 肝炎からの肝発癌を抑制しうる効果的な治療を開発 したいと考えている.

平成17年 7 月 11 日受理
はじめに

著者は山口大学医学部卒業後, 直ちに第一内科 (現, 先端分子応用医科学講座消化器病態内科学) に入局し 2 年間の臨床研修を行った後, 肝臟班に所 属した。肝臓班では主としてB型肝炎，C型肝炎を 中心としたウイルス肝炎の病態と治療に関する研究 を行ってきた，本総説では紙面の都合上，B型肝炎 に関する研究については割愛させていただき，C型 肝炎ウイルス $(\mathrm{HCV})$ の持続感染機序に関する研 究と, 現在進行中のC型肝炎における酸化ストレス からみた肝発癌機構に関する研究を紹介させていた だくことにする。

\section{I 末梢血単核球細胞内におけるHCV感染}

HCVはB 型肝炎ウイルス同様, 肝細胞親和性を持 つ肝炎ウイルスであるが, 末梢血単核球細胞内 (PBMC) にも感染しうるウイルスである. HCVが クローニングされて以来, HCVがPBMC内で増殖 しうるか否かについては論議の的であったが, 著者 らはHCVの外被タンパク内に存在する超可変領域 に注目して，HCVのPBMC内での感染を明らかに した ${ }^{1,2)}$ ・まず，C型肝炎患者の血清及びPBMCよ り $\mathrm{HCV}$ RNAを 增幅 し, Single-strand conformational polymorphism（SSCP）法を用いて 各々の超可変領域のquasispecies（遺伝子相同性） を比較したところ，18\%の患者では血清とPBMCで のquasispeciesが異なり，かつ経時的にも変化した。 
これによりPBMCから増幅されたHCV RNAは単に PBMCに付着したHCVに由来するものではないこ とが明らかにされた1)。そこで, PBMC内のHCVの quasispeciesが肝臓内のそれと本当に異なるのか否 かを明らかにするために，C型肝炎患者の血清， PBMC, 肝組織より HCV RNAを増幅し, 超可変領 域をクローニングした後塩基配列を決定し，各々の quasispeciesを比較検討した。その結果，23\%の患 者に押いては, 血清, PBMC, 肝臓でのmajor cloneが互いに異なり, さらにアミノ酸の変異率か らみたquasispeciesの程度はPBMCが最も低いこと が明らかとなった ${ }^{2}$.

以上の成績から, PBMC内でのHCV 感染が明ら かとなっただけでなく, 超可変領域が宿主の免疫応 答により多彩に変異しうることを考慮すると, PBMC内のHCVのquasispeciesの程度が最も低かっ たことは，PBMC内のHCVが宿主の免度応答から 回避し, $\mathrm{HCV}$ の持続感染において重要な役割を果 たすと考えられた。

\section{II 超可変領域の変異による液性免疫からの回避}

超可変領域はHCVの外被タンパク内に存在する ことから中和抗体のエピトープが存在するという報 告が多く見られる。一方，HCV粒子の一部は循環 血液中に打いてこの中和抗体と免疫複合体を形成し て存在することが明らかにされている ${ }^{3)}$.そこで $\mathrm{HCV}$ 免疫複合体を形成する中和抗体が真に超可変 領域に対して特異的であるか否かを明らかにするた めに, C型慢性肝炎患者の血液中のHCV免疫複合体 と複合体を形成しない非複合体粒子について HCV 超可変領域のquasispeciesを比較した。その結果, 両粒子には全く異なるquasispeciesが形成される症 例が存在し, HCV免疫複合体を形成する中和抗体 は超可変領域に対して特異的と考えられた ${ }^{4)}$. そこ でHCVの持続感染機序の一つとして液性免疫から の回避機構を明らかにするために，HCV免疫複合 体粒子と非複合体粒子について $\mathrm{HCV}$ 超可変領域の quasispeciesを経時的に観察した。そその結果，免疫 複合体には存在しない新たなクローンが肝炎の経過 とともに産生され, 中和抗体からの逃避現象が確認 された5).

このように HCVの外被タンパク内に存在する超
可変領域はめまぐるしくアミノ酸変異を引き起こす ことにより液性免疫から回避することが明らかとな ったが, 次にこの変異が全く任意に引き起こされて いるのか，拘束性をもった変異なのかについて検討 した。C型慢性肝炎患者から経時的に得られた865 クローンの超可変領域を含む塩基配列のうち, 異な る169の塩基配列について検討した。超可変領域を 構成する 27 アミノ酸各々の変異率, 親水性, 疎水性 プロフィールについて検討するとともに, Robson の方法により超可変領域の二次構造を予測した。 そ の結果, 超可変領域内のいくつかのアミノ酸は殁ど 変異せず，アミノ酸変異が起きる部位の中でも親水 性, 疎水性プロフィールがほほ一定に保たれる部位 があることが示された ${ }^{6}$. さらに, 例え超可変領域 の異なる塩基配列により quasispeciesが形成されて も, 超可変領域内の一定の領域の二次構造は保たれ ていることが明らかとなった。

以上から，持続感染に移行したHCVは宿主から の免疫機構を回避する一手段として, PBMCに感染 したり, 中和抗体のエピトープが存在する超可変領 域の変異を引き起こしていると考えられた。

\section{C型肝炎における酸化ストレスと肝発癌}

これまで述べてきたようにHCVは持続感染を引 き起こすことにより, 結果として高率に肝癌を引き 起こす。C型肝炎はB型肝炎同様, 肝炎ウイルスに より引き起こされる疾患でありながらその肝発癌率 は大きく異なり, C型はB型の約 7 倍（肝がん白書） で, 肝細胞癌症例の約 8 割を占めている。しかしな がら，C型肝炎からの肝発癌機序は未だ不明の点が 多い。ウイルス性肝炎の肝細胞傷害機序は主として 宿主の免疫応答によると考えられているが，C型慢 性肝炎はB型慢性肝炎に比べて無症候性キャリアー の割合が低いことが知られている。これは言い換え ればC型肝炎に扔いてはウイルスによる直接的肝細 胞傷害の存在を示唆するものであり, 最近の研究か らこの直接的肝細胞傷害機序のひとつとして酸化ス トレスの関与が注目されている7-9).したがってC 型肝炎ウイルス（HCV）が惹起する酸化ストレス が高率な肝発癌に関与しているのではないかという 仮説が成り立ち, 事実この方面での新たな知見が集 積されつつある。本総説ではわれわれの知見も含め 
て酸化ストレスからみたC型肝炎の肝発癌機構につ いて考察する。

(1) HCVコアタンパクによる酸化ストレスの誘導 HCVコアタンパクの発現が調節可能な培養細胞 系（Huh-7とHeLa）を用いた検討からは，HCVコ アタンパクが直接的に活性酸素を産生させることが 明らかにされている10).In vivoにおいても HCV アタンパクを発現する16ヶ月齢以上のトランスジェ ニックマウス（TgM）の肝臓では, 炎症が存在し ないにもかかわらず有意に脂質過酸化物二次性生物 の量が高いことが明らかにされている11).一方，C 型慢性肝炎患者の肝組織像の特徴のひとつとして肝 細胞の脂肪化が知られているが，脂肪化のある肝臓 では，脂肪化がない肝臟に比べて有意に脂質過酸化 物二次性生物量（この場合は4-hydroxy-2-hexenal） が多く，C型肝炎における肝脂肪化も酸化ストレス と密接に関連していることを明らかにした ${ }^{12}$.

ではこうしたHCVコアタンパクによる酸化スト レスの誘導機序はどのように考えられるのであろう か. 細胞内における活性酸素の最大産生部位がミト コンドリアであることはよく知られている，HCV コアタンパクはミトコンドリア電子伝達系の複合体 I の酵素活性を障害することにより電子の伝達を遅 延させ，その結果として活性酸素を産生すると考え られている ${ }^{13}$. HCVコアタンパクがどのようにして 複合体 I に作用するのかは今後の研究課題である が，最近HCVコアタンパクのC端側にミトコンドリ ア移行シグナルが存在し，コアタンパクが実際にミ トコンドリア外膜に結合しうることが報告されてい $ろ^{14)}$.

(2) 酸化ストレス下でのHCVコアタンパクによるア ポトーシス抑制効果

一方，細胞内においてHCVコアタンパクにより 誘導される酸化ストレスのマグニチュードはそれほ ど大きいものではないが，このようにわずかな酸化 ストレスによっても酸化的DNA障害の指標の一つ である8-hydroxy-2'-deoxyguanosine（8-OHdG）が 有意に蓄積されることが明らかとなった ${ }^{15)}$.しかし， 細胞内に打ける活性酸素の産生はミトコンドリア障 害を増幅し, 結果として細胞がアポトーシスに陥り やすくなることもよく知られた事実である。 そこで
HCV コアタンパクによる酸化的DNA障害の存在下 で，HCVコアタンパクがアポトーシスに与える影 響について検討した。その結果，アポトーシス調節 分子である Bcl 2ファミリーのうちアポトーシス抑 制分子であるBcl-xLの発現が充進し，アポトーシス 促進分子であるBaxの発現が低下していることが明 らかとなった。すなわちHCVコアタンパク発現細 胞において活性酸素を産生し, 酸化的DNA障害を 惹起する一方で，アポトーシスに抵抗性であること は，HCV感染に打ける肝発癌過程を考えるうえで 興味深い知見であると考えられた。しかし， HCV コアタンパクが細胞のアポトーシスに与える影響 は，用いる細胞やアポトーシス誘導因子の違いによ り光進と抑制の両面からの報告があり, 更なる検討 を要すると考えられる。

\section{(3) HCV肝発癌における鉄過剩の意義}

以上から，HCVによる酸化ストレスの発現が肝 発癌において重要な役割を果たすと推測されるが, $\mathrm{HCV}$ 自体が誘導する酸化ストレスのマグニチュー ドはそれほど大きいものではない。臨床的にも $\mathrm{HCV}$ 持続感染者が均一に発癌するわけではなく, 高齢者, アルコール多飲者, 線維化進展者など肝発 癌の高危険群が存在する. 加齢やアルコールは酸化 ストレス誘導因子であり, 逆に酸化ストレスにより 肝線維化が進行することも知られている，すなわち HCV自体の酸化ストレス誘導に加えて, 2nd hitと しての酸化ストレスの増強が肝発癌には重要と考え られる。一方，C型慢性肝疾患患者では肝内の鉄過 剩状態が明らかにされている ${ }^{16}$. 何故, 鉄過剩状態 が引き起こされるかについては未だ明らかではない が，鉄は強力な活性酸素を産生させる。 そこで，わ れわれは酸化ストレスの増強因子として鉄に注目 し, HCV感染での肝発癌における鉄の役割を明ら かにしたいと考えている。

(4) 鉄過剩HCVトランスジェニックマウスによる肝 発癌の検討

HCV 全遺伝子が組み达まれたトランスジェニッ クマウス（HCV TgM）に鉄過剩食を与えることに より，C型慢性肝炎に類似した肝内鉄濃度の $\mathrm{HCV}$ TgMを作成した。このTgMと同系のC57BL/6マウ ス（BL6）をコントロールとし，8 週例のTgMと 
BL6にそれぞれ鉄過剩食（Fe群：鉄含有 $225 \mathrm{mg} / \mathrm{g}$ ) または通常食（control群：鉄含有 $45 \mathrm{mg} / \mathrm{g}$ ) を投与 する 4 群を設定した。 4 群間での平均食䬣摂取量や 経時的な体重増加には差を認めなかったが, TgM $\mathrm{Fe}$ 群の肝内鉄含有量は最も多く，6〜10ヶ月の鉄 過剩食投与により約 $200 \mu \mathrm{g} / \mathrm{g}$ liver weightに達し, C型慢性肝炎患者のそれに近似した。さらに，鉄染 色により肝内の鉄の局在を検討したところ，大半は 肝細胞内に鉄の沈着を認め, Kuppfer細胞には殆ど 認めなかった。 6 ケ月目のTgM control群や12ヶ月 目のBL6 Fe群でも軽度のsteatosisを認めたが, $\mathrm{TgM}$ Fe群は 6 ヶ月目以降Zone IIIのmicrovesicular steaosisも混じた著明なsteatosisを認めた。この TgMは肝内に炎症を起こすことなく, 脂肪沈着を 引き起こすことが明らかにされているが17)，鉄負荷 によりsteatosisが増強したと考えられる。また酸化 ストレスの指標としての肝内脂質過酸化物（4-HNE 及び4-HHE）陽性面積と肝内8-OHdG量はTgM Fe 群が他の 3 群にくらべ有意に高かった。 ミトコンド リアの超微形態はTgM Fe群において大小不同, ク リスタの消失，巨大ミトコンドリア等を示し，明ら

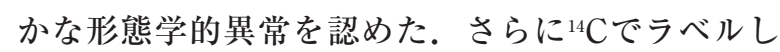
たパルミチン酸を投与し脂肪酸代謝能を比較検討し たが，TgM Fe群が他の 3 群に比べて有意に低下し ており，ミトコンドリア機能障害も認めた，最も興 味深いことに，飼育開始 9 ケ月目まではいずれの群 においても肝腫瘍を認めなかったが，12ヶ月目では TgM Fe群においてのみ肝細胞癌を含む肝腫瘍を11 匹中 5 匹 $(45 \%)$ に認めた。このHCV TgMはもと もと13ヶ月齢以上の雄において肝発癌を認めること が報告されているが17)，今回の検討から HCV感染に おける鉄過剩状態はミトコンドリア障害を引き起こ し，酸化ストレスを増強することで肝発癌を促進す ることが明らかとなった。

\section{おわりに}

著者のC型肝炎に関する研究対象はその持続感染 機序の解析から始まり, 現在はHCV持続感染が究 極的にもたらす肝発癌機構の解明へと変遷してき た。

C型慢性肝炎の治療はペグインターフェロン・リ バビリン併用療法の導入により, 難治型症例に対し
ても約50\%のウイルス排除が可能になった.しかし， 未だ半数の患者はウイルス排除ができないまま, 肝 発癌抑制のために闘病生活を余儀なくされている。 ようやくC型肝炎患者に類似した肝発癌モデルを作 成することができたので，今後は肝発癌抑制のため の新たな治療を構築していきたいと考えている.

最後に，著者が肝臓班に所属して以来，ご指導い ただいた沖田 極 前教授，肝炎研究を共に行って きた肝炎グループの大学院生, 指導医の先生方, 卜 ランスジェニックマウスをご供与いただいた Lemon教授，Weinman教授（テキサス大学ガルベ ストン校)，電子顕微鏡のご指導をいただいた権藤 俊一先生（山口大学医学部附属病院病理部）に深謝 致します。

\section{文献}

1 ) Fujii K, Hino K, Okazaki M, Okuda M, Kondoh S, Okita K. Differences in hypervariable region 1 quasispecies of hepatitis $\mathrm{C}$ virus between human serum and peripheral blood mononuclear cells. Biochem Biophys Res Commun 1996 ; $225: 771-6$.

2 ) Okuda M, Hino K, Korenaga M, Yamaguchi Y, Katoh Y, Okita K. Differences in hypervariable region 1 quasispecies of hepatitis $\mathrm{C}$ virus in human serum, peripheral blood mononuclear cells, and liver. Hepatology $1999 ; 29: 217-22$.

3 ) Hijikata M, Shimizu YK, Kato H, Iwamoto A, Shih JW, Alter HJ, Purcell RH, Yoshikura H. Equilibrium centrifugation studies of hepatitis C virus: evidence for circulating immune complexes. J Virol 1993; 67 : 1953-8.

4 ) Korenaga M, Hino K, Okazaki M, Okuda M, Okita K. Differences in hypervariable region 1 quasispecies between immune complexed and non-immune complexed hepatitis $\mathrm{C}$ virus particles. Biochem Biophys Res Commun $1997 ; 240: 677-82$.

5 ) Korenaga M, Hino K, Katoh Y, Yamaguchi Y, Okuda M, Yoshioka K, Okita K. A possible role of hypervariable region 1 quasispecies in 
escape of hepatitis $\mathrm{C}$ virus particles from neutralization. J Viral Hepat 2001 ; 8 : 331-40.

6 ) Hino K, Korenaga M, Orito E, Katoh Y, Yamaguchi Y, Ren F, Kitase A, Satoh Y, Fujiwara D, Okita K. Constrained genomic and conformational variability of the hypervariable region 1 of hepatitis $\mathrm{C}$ virus in chronically infected patients. $J$ Viral Hepat $2002 ; 9: 194-201$.

7 ) Barbaro G, Di Lorenzo G, Asti A, Ribersani M, Belloni G, Grisorio B, Filice G, Barbarini G. Hepatocellular mitochondrial alterations in patients with chronic hepatitis C: ultrastructual and biochemical findings. Am J Gastroenterol 1999 ; 94 : 2198-2205.

8 ) Kageyama F, Kobayashi Y, Kawasaki T, Toyokuni S, Uchida K, Nakamura H. Successful interferon therapy reverses enhanced hepatic accumulation and lipid peroxidation in chronic hepatitis C. Am J Gastroenterol 2000 ; 95 : 1041-1050.

9 ) Paradis V, Mathurin P, Kollinger M, mbertBismut F, Charlotte F, Piton A, Opolon P, Holstege A, Poynard T, Bedossa, P. In situ detection of lipid peroxidation in chronic hepatitis $\mathrm{C}$ : correlation with pathological features. J Clin Pathol 1997 ; 50 : 401-6.

10) Okuda M, Li K, Beard MR, Showalter LA, Scholle F, Lemon SM, Weinman SA. Mitochondrial injury, oxidative stress, and antioxidant gene expression are induced by hepatitis C virus core protein. Gastroenterology $2002 ; 122: 366-75$.

11) Moriya K, Nakagawa K, Santa T, Shintani $Y$, Fujie H, Miyoshi H, Tsutsumi T, Miyazawa T, Ishibashi K, Horie T, Imai K, Todoroki T, Kimura S, Koike K. Oxidative stress in the absence of inflammation in a mouse model for hepatitis $\mathrm{C}$ virus-associated hepatocarcinogenesis. Cancer Res $2001 ; 61: 4365-70$.

12) Kitase A, Hino K, Furutani T, Okuda M, Gondo T, Hidaka I, Hara Y, Yamaguchi Y, Okita K. In situ detection of oxidized n-3 polyunsaturated fatty acids in chronic hepatitis C: correlation with hepatic steatosis. $J$ Gastroentrerol (in press).

13) Korenaga M, Wang T, Showalter L, Chan T, Sun J, Weinman SA. Hepatitis C virus core protein inhibits mitochondrial electron transport and increases ROS production. (in submitted).

14) Schwer B, Ren S, Pietschmann T, Kartenbeck J, Kaehlcke K, Bartenschlager R, Yen TS, Ott $\mathrm{M}$. Targeting of hepatitis $\mathrm{C}$ virus core protein to mitochondria through a novel C-terminal localization motif. J Virol 2004 ; 78 : 7958-68.

15) Hara $Y$, Hino K, Furutani T, Okuda M, Hidaka I, Yamaguchi Y, Korenaga K, Li K, Weinman SA, Lemon SM, Okita K. Hepatitis C virus core protein inhibits deoxycholic acidmediated apoptosis despite generating mitochondrial reactive oxygen species. (in submitted).

16) Farinati F, Cardin R, De Maria N, Della Libera G, Marafin C, Lecis E, Burra P, Floreani A, Cecchetto A, Naccarato R. Iron storage, lipid peroxidation and glutathione turnover in chronic anti-HCV positive hepatitis. $J$ Hepatol $1995 ; 22: 449-56$.

17) Lerat H, Honda M, Beard MR, Loesch K, Sun J, Yang Y, Okuda M, Gosert R, Xiao SY, Weinman SA, Lemon SM. Steatosis and liver cancer in transgenic mice expressing the structural and nonstructural proteins of hepatitis C virus. Gastroenterology 2002 ; $122: 352-65$. 


\title{
Persistent Infection of Hepatitis C Virus and Hepatocarcinogenesis
}

\author{
Keisuke HINO \\ Department of Basic Laboratory Sciences, Faculty of Health Science, \\ Yamaguchi University School of Medicine, \\ 1-1-1 Minami Kogushi, Ube, Yamaguchi 755-8505, Japan
}

\begin{abstract}
SUMMARY
I herein discuss the two subjects on hepatitis $\mathrm{C}$ virus ( $\mathrm{HCV}$ ) infection by showing some data obtained from our research. First, I discuss the mechanisms by which HCV evades host immune surveillance. Differences in HCV quasispecies between liver and peripheral blood mononuclear cells (PBMCs) suggest infection of PBMCs by HCV and that HCV in PBMCs may be differently exposed to host immunity from that in liver. As an another mechanism for persistent infection of HCV, major HCV clones escape from neutralization by neutralizing antibodies by generating considerably divergent minor "decoy" clones which may be preferentially neutralizaed. Second, I discuss the mechanisms by which hepatocellular carcinoma (HCC) develops in persistent $\mathrm{HCV}$ infection, especially focusing on the oxidative stress induced by HCV. We established iron overloaded HCV transgenic mice which have almost the same iron content in the liver as that in patients with chronic hepatitis $\mathrm{C}$ and develop HCC in twelve months. By analyzing these animals, it has been shown that the development of HCC is closely related to the synergistic oxidative stress induced by HCV core protein and iron overload.
\end{abstract}

